\title{
Governance of the South African University under Democracy and the Triumphalism of Managerialism over Transformational Leadership
}

\author{
Professor Johannes Tsheola \\ Ms Phophi Nembambula
}

Department of Development Planning \& Management, University of Limpopo, South Africa P.O. Box 313, Fauna Park, 0787, South Africa

johannes.tsheola@ul.ac.za

Doi:10.5901/mjss.2014.v5n27p1655

\begin{abstract}
Universities are by their origin controversial and contested public spaces, with perennially precarious relationships with the state and society. The South African University has not been an exception to this norm; and, political democratization necessitated its restructuring and transformation into learning organization. This article argues that the Department of Higher Education and Training's (DoHET's) 2008 interventions have ironically reinforced the triumph of managerialism over transformational leadership in the governance of the South African University. Reverence for managerialism and overbureaucratization eroded the necessary public spaces for innovativeness, imaginativeness, risk-taking, application of common sense and experimentation required for the transformation of the South African University. The most vivid manifestation of the triumph of managerialism is in the DoHET's technocratic funding model for the South African University. The article concludes that the potential for transformational leadership has faced intractable governance dilemmas of a disabling environment that is diametrically opposed to qualities of charisma, inspiration, intellectual stimulation and individual consideration. It suggests that the present South African University yawns for re-humanize, democratization and collaborative strategies which place emphasis on personal relationships, cross-cultural communications, integration of heart and head as well as judicious mix of soft and hard tactics, given the historical legacies of apartheid and racial segregation.
\end{abstract}

Keywords: Governance; Managerialism; Transformational Leadership; the South African University

\section{Introduction}

Universities, by nature of their core business, have been in a perennial relationship of precarious flux with society and state (Nolte, n.d.; Jansen, 2003; Cassim, 2005; Vinger \& Cilliers, 2006; Dominguez-Whitehead, 2011). State-funded, universities are required to be creative and innovative to maintain theoretical and policy relevance (Jansen, 2003; Mkandawire, 2005, 2011; Chipunza \& Gwarinda, 2010). However, nuance state interventions in university governance and marketization imperatives have recreated these institutions into virtual state-owned enterprises for deleterious public contestations (Mkandawire, 2005, 2011). As Mkandawire (2011, p.15) puts it, the African University has generally been subjected to "incontinent insistence on conformity and sycophancy by authoritarian rulers". Everywhere else, the stateuniversity conflict has involved matters of authoritarianism, institutional autonomy and academic freedom (Jansen, 2003; Mkandawire, 2005, 2011; du Toit, 2014), amidst localized geopolitics of divergent visions as well as internationalization and globalization imperatives (Jansen, Habib, Gibbon \& Parekh, 2001; Jansen, 2003; Jack, 2007; Chipunza \& Gwarinda, 2010).

On its part, the South African University, especially the historically disadvantaged, has been characterized by protest (Dominguez-Whitehead, 2011). A democratic South Africa embarked on a series of restructuring policies, variously interpreted as attempts to wrestle power from universities and eroding scope for institutional autonomy and academic freedoms (Cassim, 2005; du Toit, 2014). Necessitated by political transformation, restructuring of the South African University exacerbated the turbulence, uncertainty and high turnover of academic leadership. Simultaneously, universities were required to creatively find a niche that would be "most compatible" with their "inherent" strengths and opportunities (Nolte, n.d., p.135) and to transform and recreate themselves into learning organizations. But the increasing presence of the state in the governance of the South African University manifested in apparent reverence for and triumphalism of managerialism over transformational leadership. University governance came to be dominated by technocratic managerialism at the expense of creativity, experimentation, intellectual stimulation and innovativeness. 
Consumed with technocratic managerialism, university faculty lost academic inspiration relating to appealing vision, roles and principles for finding societal solutions.

For these reasons, the Chief Executive Officer of Higher Education South Africa (HESA) describes the tertiary sector as "a complex and ever-changing" landscape, with much at stake (cited in du Toit, 2014). Whereas the imperatives of internationalization and "globalization affected institutional behaviour, processes and structures" (Levin, 1999, p.383 cited in Jansen et al., 2001, p.32), democratization honeymoon of co-operative governance was ephemeral (Jansen, 2003; Chipunza \& Gwarinda, 2010; du Toit, 2014). In practice, co-operative governance meant that the state consolidated power of interference in the governance of universities in the guise of redressing past imbalances and inequality (Jack, 2007; Toni, 2011). Indeed, universities are capable of poignantly epitomizing development and nation-building, beyond mere production of human capital and manpower (Jansen, 2003; Beckman \& Adeoti, 2006; Mkandawire, 2005, 2011). Hence, Mkandawire (2011, p.15) concludes that the African University's limitation in respect of "material infrastructure and academic freedom" has rendered the continent flagrantly opaque. The South African University does not escape this characterization because political transformation has entailed complex governance that involves free market competition for resources with virtual, private and corporate universities, wherein public good education is reinvented as a commodity and students being recreated into customers (Nolte, n.d.; Jansen, 2003; Jack, 2007; Louw \& Zuber-Skerritt, 2009; Chipunza \& Gwarinda, 2010).

The requirement for the South African University to foster "new institutional culture and identity" whilst the Department of Higher Education and Training (DoHET) remained reluctant to increase funding, sustaining therefore the thin resources base, compounded the historical legacies of inequality (Jansen, 2003; Jack, 2007). Historically, the South African University was racially fragmentary; and, democratic restructuring has involved several policy and legislative shifts from the 1996 "co-operative governance" framework to the 2012 amendments that extended the power of the state in university governance (du Toit, 2014). This article argues that governance of the South African University in the democratic era is captivated by debilitating technocratic managerialism, which entails bureaucratic rigidities that are not amenable to the necessary characters of institutional autonomy, academic freedoms, innovativeness, experimentation, academic inspiration, intellectual stimulation and transformational leadership. It illustrates this argument by using the rigidities of the DoHET's funding model for the South African University.

\section{Governance: Managerialism Versus Transformational Leadership}

Paradigm shift from government to governance raised questions of conceptualization of the relationship between the state and state-funded institutions such as universities and state-owned enterprises (Jansen, 2003; du Toit, 2014). Ironically, government shifted from the centre only to become "a powerful partner in a multitude of governing arrangements" (Cloete et al., 2002, pp.90-91 cited in du Toit, 2014, p.26). The notion of governance was supposed to signal "mutual dependence between state and civil society" (NCHE, 1996, p.172; du Toit, 2014, p.26) and to emulate corporate sector ethos and practice. With the governance rhetoric, the South African University too was increasingly coerced "into a more competitive, international 'education industry"' wherein the requirement to "compete for resources by adopting a 'market focus'" became imperative (Cassim, 2005, pp.663-664). The nuance forms of governance, inclusive of co-operative governance, for universities were variously construed as attacks on institutional autonomy, academic freedoms as well as recreating these institutions into state-owned enterprises. For the South African University, though, du Toit (2014) asserts that there was never institutional autonomy, both in principle and practice. Whereas the concept of co-operative governance was intended to emphasise the interdependence of social partners, in practice the state used it to extend its control over the South African University.

\subsection{Managerialism and Over-Bureaucratization}

A series of factors shape and reshape higher education across the world; and, these include globalization, internationalization, reduction of public funding as well as heightened focus on spending accountability and knowledge management approaches (Nolte, n.d.; Jansen, 2003; Jack, 2007; Chipunza \& Gwarinda, 2010). Commonly, universities have adopted nuance managerialism governance as a response (Nolte, n.d.; Jansen, 2003; Louw \& Zuber-Skerritt, 2009; Chipunza \& Gwarinda, 2010). Given the continued pressure of globalization, internationalization, technological developments, politics, economics and sociocultural dynamics, universities have been forced to adopt private market ethos and to adapt to market philosophy, whilst traditional "distinctions between education and business, profit orientation ... (and) non-profit orientation, and students as clients, customers or consumers" increasingly blurred with the private market gaining primacy (Nolte, n.d.; Jansen, 2003; Jack, 2007; Louw \& Zuber-Skerritt, 2009; Chipunza \& Gwarinda, 
2010). Within this context, the traditional "centralized legal-bureaucratic management" of universities as well as the claim for institutional autonomy, academic freedoms and self-management were increasingly eroded (Nolte, n.d.; Jansen, 2003; Louw \& Zuber-Skerritt, 2009; du Toit, 2014). Simultaneously, managerialism gained traction in universities governance as private sector business practices found increased application in public institutions such as state-owned enterprises. Nuance forms of managerialism involved the introduction of total quality management, re-engineering, strategic management, continuous organizational renewal, competitiveness, performance management, balanced scorecards, budgeting cost centres, teamwork, setting goals and targets, control and monitoring mechanisms as well as efficiency requirements (Deem 2001, pp.10-11 cited in Nolte, n.d., p.124). Effectively, the South African democratic state proffered adherence to managerial leadership or managerialism for universities' governance (Dominguez-Whitehead, 2011).

With the adoption of managerialism, the discourse about university governance blurred with that for private corporations in an environment rife with notions of "accountability", "executive management" and "line managers", which translate into performance measurement, staff job vulnerability and insecurity, focus on competition and markets, as well as "corporate management values, ideologies and techniques" (Gwele, 2008, pp.322-324 cited in Dominguez-Whitehead, 2011, p.1313). The mushrooming of corporate, virtual and private universities added to the complexity of public institution governance; and, this phenomenon ironically highlighted tacit acceptance that the private market ethos are not entirely applicable to public investments. However, "new managerialism rendered leadership and governance competency 'an imperative for progress'" and survival of the South African University (Nolte, n.d., p.126), affecting therefore the balance of institutional autonomy, academic freedoms and exercise of state power (Jansen, 2003; Louw \& Zuber-Skerritt, 2009; du Toit, 2014). As a result, managerialism for governance of the South African University came to be clouted with tensions, power struggles, risk-prone decision-making and countless political considerations (White, Riordan, Ozkanli \& Neale, 2010; Dominguez-Whitehead, 2011; White, Carvalho \& Riordan, 2011). Understandably, Dominguez-Whitehead (2011, p.1325) concludes that the "new managerialism apparent at institutions of higher education has disrupted traditional collegial governance structures and has pitted management against staff (including academic staff), leading to antagonism and distrust".

Apparently, the South African University has sought to adopt "collegiality leadership model" wherein "decisions of academics in relation to students' marks, are rarely questioned .... Professors professed; deans led; councils governed; administrators administered; and students studied" (Dominguez-Whitehead, 2011, p.1312-1313). These traditions have not held as the state interfered even in the norms set for pass, graduation and throughput rates. As this article will demonstrate later, state funding of the South African University is now firmly based on the full-time equivalents (FTEs) that are inextricably linked with modules passed and overall throughput rate of qualifications. Inescapably, managerialism translated into vexed challenges for university governance because private sector market philosophy is not entirely applicable to public institutions. Already, there are insinuations that universities have become nuance hybrid of stateowned enterprises, notwithstanding the unresolved issues of appropriateness, effectiveness, usefulness and efficiency of the nuance forms of managerialism. Undoubtedly, the cultures, purposes and operational goals of the private and public sectors are divergent and, sometimes, irreconcilable. Yet, the South African University is presently preoccupied with managerialism. The requirement for managerialism is an overbearing detraction for the South African University governance, given that the institution is by its nature supposed to be preoccupied with knowledge production and exchange with industry, civil society and the state through boundary-spanning activities as a knowledge hub. The most pragmatic alternative to over-bureaucratization and managerialism of the South African University governance is in transformational leadership for.

\subsection{Transformational Leadership}

There are multiple types and styles of leadership including managerial, transactional, transformational, self-developed, "pack", principle-centred, "failing-forward" and laissez faire (Northouse, 2001; Vinger \& Cilliers, 2006; Jack, 2007; ZuberSkerritt, 2007; Louw \& Zuber-Skeritt, 2009; Chipunza \& Gwarinda, 2010; Dominguez-Whitehead, 2011). Nuance paradigm emphasizes collaboration, personalized relationships, cross-cultural communications, democratization and humanization of university governance above rationalization, control and over-bureaucratization (Jansen, 2003; ZuberSkerritt, 2007; Louw \& Zuber-Skeritt, 2009). Whereas "pack" leadership relies on the ideals of team work, leading is in the final analysis a function of "cognitive, affective, motivational and interpersonal" characteristics (Vinger \& Cilliers, 2006, p.7). Leadership is overwhelmingly qualitative, involving learning and participatory processes, collaborative strategies, humanization and democratization (Jansen, 2003; Zuber-Skerritt, 2007; Louw \& Zuber-Skerritt, 2009; Chipunza \& Gwarinda, 2010). However, the imperatives of internationalization and globalization, state interventionism and the pervasiveness market competition have made the exercise of transformational leadership more complex than 
managerialism. In practice, universities leadership entails a judicious mix of "pack" and individual capabilities. As social systems, universities consist of different personalities and characters, implying that understanding individuals' depence on "subjectivities" to experience life is inextricably intertwined with transformative leadership's "lived" experiences of formal and informal interactions in the process of which interventions and transcations are made to redress historical legacies of injustcies and inequities. Far from managerialism, governance of the South African University entails transformational leadership because of the turmoil, instability and uncertainty embeded therewith, continuous policy chifts and unending legislative changes that do not support the creation of learning organizations.

Transformational leadership inculcates trust, admiration, loyalty and respect for the leaders whilst motivating subordinates to perform more than originally expected through the four basic "I's": idealized influence (charisma); individualized consideration; intellectual stimulation; and, inspirational motivation (Northouse, 2001; Vinger \& Cilliers, 2006). Based on these four basic components, transformational leadership communicates an appealing vision with simple symbols and images in order to focus the efforts of subordinates, raise their emotions to emulate and to identify with leaders, coach and encourage them with supportive feedback, delegation and advice for their personal development, as well as motivate for acute awareness of problems and the requirement for creativity, innovation and ability to take measured risks (Northouse, 2001; Vinger \& Cilliers, 2006). Given that change also leads to anxiety, anger, depression, tension, disenchantment and helplessness (Northouse, 2001; Vinger \& Cilliers, 2006), transformational leadership embrace them as part of individualized governance consideration. Under transformation, university governance requires leadership that is intelligent, experienced, substantially self-confident, effective, progressive, constructive, innovative, courageous, bold, decisive, generalist, specificist, directive, futuristic as well as being capable of perseverance, taking control, exercising balanced judgment, relying on common sense, taking calculated risk, promoting experimentation in uncharted territories, adopting unconventional solutions, defying odds and holding positive mindset (Nasser \& Vivier, 1993, p.154 cited in Nolte, n.d., p.134). Whereas the requirement for effective transformational leadership is selfexplanatory for universities, the adoption of an empowerment approach that motivates, coaches, encourages and provides vision and direction has not always been an automatic choice for their governance (Nolte, n.d.; Jansen, 2003; Louw \& Zuber-Skerritt, 2009; Chipunza \& Gwarinda, 2010).

Taking from Balster (2002), Chipunza \& Gwarinda (2010) assert that transformational leadership, traceable to the concept of transactional leadership, provides the framework, principles, character and roles that are required for governance of the South African University. Whereas transactional leadership relates to exchange and promise of rewards for effort as well as responsiveness to immediate interests of the subordinates, transformational leadership "involves charisma, inspiration, intellectual stimulation and individual consideration" (Bass, 1990 and Balster, 2002 cited in Chipunza \& Gwarinda, 2010, p.2). Charismatic leaders are capable of instilling pride, respect and trust in the institution's stakeholders by vigorously ensuring that the institutional vision and mission are commonly shared (Chipunza \& Gwarinda, 2010). Such leadership sets and communicates high expectations using symbols and images "to focus efforts" and to express "important purposes in simple ways" (Chipunza \& Gwarinda, 2010, p.2). Also, it uses intellectual stimulation "to promote intelligence, rationality and careful problem solving" (Avolio, Waldman \& Yammarino, 1991 cited in Chipunza \& Gwarinda, 2010, p.2). Finally, as Chipunza \& Gwarinda (2010, p.2) put it, transformational leadership "gives personal attention, treats each employee individually and coaches and advises, thus giving individualized consideration to employees". Drawing from these four characteristics, Chipunza \& Gwarinda (2010, p.2) formulates four transformational leadership roles: developing shared vision and defining its value and principles; communicating strategic direction and clarifying its content and meaning; empowering subordinates by allowing them decision-making authority and access to information relevant for supporting progressive change, as well as rewarding them for risk-taking and innovativeness; and, developing capacity for change, preparing subordinates for readiness to participate in transformation through skills training as well as catering for their emotional well-being. That is, transformational leadership inspires subordinates to exert effort and perform in accordance with the change required, by instilling a sense of security to enhance self-worth, emotional anchorage, self-esteem and personal strength (Zuber-Skerritt, 2007).

Transformation of the South African University entails active qualitative governance, rather than passive overbureaucratized managerialism. For South Africa, as Vinger \& Cilliers (2006) adjudge, laissez faire leadership is nonleadership governance because universities, as organizations, are incessantly involved in change, planned and unplanned. University leadership needs to be actively involved in mobilizing, inspiring, instilling confidence and focusing efforts of subordinates on the vision of the institution; and, laissez faire leadership erroneously "abdicates responsibilities and avoids making decisions" (Vinger \& Cilliers, 2006, p.2). On its part, transformational leadership is enterprising, communicative, open-minded, inspirational, capable of pep talks, knowledgeable of macro- and micro-environment, recognizes the significance of continuous information gathering, committed to lifelong learning and education, and able to clearly articulate an appealing vision (Northouse, 2001; Vinger \& Cilliers, 2006). In practice, the South African University 
has increasingly been trapped in red tape, fixed hierarchical bureaucracies, rigid adherence to performance measurement policies and procedures, avoidance of dysfunctional conflict and taking mistakes and failures as normal occurrences of learning. Being forthright has often been criticized as "inconsiderate, inhumane, disrespectful, unreasonably confrontational, 'devilish', not caring, and lacking people skills" (Vinger \& Cilliers, 2006, p.6). But the South African University consists of multiple, diverse cultures and histories; and, democratization has necessitated restructuring and transformation of the university system. Universities are simultaneously global, national and local because they are everywhere "nested in national government" and "shaped by patterns of social investment", with much decision-making controlled by the state or framed through national public interests and political contexts (Marginson, 2010). Hence university academia matters "if only because they are significant in the interstices between the state and civil society" (Mkandawire, 2011, p.22). The potential for exercise of transformational leadership has, therefore, been a function of the state's policy and legislative determination. Universities continue to require public funding to be sustainable, but being employed there is often characterized as "working within a contentious environment" (Dominguez-Whitehead, 2011, p.1313). As a result of their positioning and position-making, universities are plagued by disruptive protests and strikes occasioned by dissatisfied students, academics and support staff (Oxlund, 2010; Dominguez-Whitehead, 2011). These incidents add to the complexity faced in governance of the South African University, given triumphalism of institutionalized managerialism.

\section{Governance of the South African University}

Simultaneously as Africa recorded the "fastest growing university population in the world", democratization struggles renewed interest in university governance, thereby widening "intellectual space for academics" and providing "respite from the suffocating atmosphere of authoritarianism" and giving "greater political protection" to these institutions (Mkandawire, 2011, p.24). But this phenomenon involved "mushrooming of private universities and centres of excellence", whose intellectual sustenance continued to paradoxically depend heavily on public universities which have historically, proven to be resilient in the face of instability, turbulence, turmoil, uncertainty, authoritarianism and tribulations (Jansen, 2003; Mkandawire, 2005, 2011; du Toit, 2014). The South African University has not been immune from these dialectical dilemmas of internal and external geopolitics. With political democratization, the South African University came to "grapple with transformation and with reinventing" itself as a learning organization (Cassim, 2005, p.664). Under democracy, the South African University faced "a plethora of challenges" including national financial aid system, poor graduation rates, student housing and faculty management (Dominguez-Whitehead, 2011, p.1310). Consequently, there was urgent need to establish "a unifying organizational culture, requisite for dismantling cultural, identity and hegemonic boundaries that are residues of the previously racialized" apartheid education system (Toni, 2011, p.187). After mergers and incorporations, South Africa remained with 23 universities (White, Riordan, Ozkanli \& Neale, 2010; Tilak, 2011).

Concluding her inaugural lecture, Mkandawire (2011, p.25) eloquently demonstrates the strong connection between university, state, society and development thus:

"... the crisis of the African university is closely related to the crisis of development. Consequently, "bringing development back in' will require a revitalization of the African University, its internal functioning and its relationships with the global world knowledge. The African University matters to Africa. .... All this immediately places a heavy burden on the African University itself. And if Africa will have to run, the university will have to sprint".

The same observation is valid for the South African University. But a democratic South Africa's restructuring exacerbated the complexity of the challenges of university governance (Jansen et al., 2001; Jansen, 2003; Chipunza \& Gwarinda, 2010). Inevitably, the requirement to foster new institutional culture and identity tended to be placed on the backseat whilst the South African University flirted with nuance managerialism (Jansen, 2003; Jack, 2007; Chipunza \& Gwarinda, 2010). Addressing historical and geographical challenges of the South African University on a "thin resource base" was always destined to be a virtual impossibility (Jack, 2007; Louw \& Zuber-Skerritt, 2009; Chipunza \& Gwarinda, 2010). Restructuring the South African University necessitated the creation of "new institutions with new identities, structures, cultures, reward systems, information processes and work designs" (Vinger \& Cilliers, 2006, p.2) which are impossible with managerialism. The complexity of transformation of the South African University has been in balancing planned enacted change with "crescive unplanned change" in their governance, under endless policy and legislative shifts. 


\subsection{Policy and Legislative Shifts in the Democratic Era}

Transformation of the higher education system in South Africa can be traced back to the 1996 National Commission on Higher Education (NCHE) Report, the 1997 White Paper on A Programme for the Transformation of Higher Education, the 2000 Council on Higher Education's (CHE) Shape and Size of Higher Education Task Team Report, the 2001 National Plan for Higher Education (NPHE) and the 2012 amendment of the laws (Nolte, n.d.; du Toit, 2014). The 1996 Green Paper on Higher Education Transformation culminated in the Higher Education Act 101 of 1997 (DoE, 1997). But restructuring of the relationships between universities, the state and society was specifically intensified in the 1997 White Paper 3: A Programme for the Transformation of Higher Education, which was amended through the Higher Education and Laws Amendment Act 23 of 2012 (DoHET, 2012). The National Working Group on Education of the Ministry of Education (MoE) recommended in 2001 the reduction of South Africa's 36 Universities and Technikons to 23, which was to be facilitated through mergers and incorporations (Jansen, 2003; MoE, 2003; Chipunza \& Gwarinda, 2010). As Barnes (2006) purports, the discourse about restructuring shifted from desirability to feasibility. But the 2012 amendments of the 1997 laws instituted major legislative changes in South Africa's higher education environment, especially in the extension of the Minister's powers to intervene, dissolve Councils and appoint Administrators for universities under a variety of guises, including "poor or non-performance" or "maladministration" (du Toit, 2014). Even with these amendments, the DoHET (2012) acknowledges the basic principles set in the DoE's Higher Education Act 101 of 1997 thus: "It is the responsibility of higher education institutions to manage their own affairs... (and that) Diversity and flexibility are important aspects of institutional responses to varying needs and circumstances". In practice, though, governance of the South African University became more complex with the extension of the powers of the Minister, which effectively thwarted all public spaces for creativity, innovativeness, imaginativeness and experimentation. According to the Vice-chancellor of the University of Johannesburg, Dr Ihron Rensburg (2013), the net effect of the 2012 amendments was to erode universities' autonomy and to transform them into virtual state-owned enterprises (cited in du Toit, 2014, p. 2). Du Toit (2014, p.3) has however disputed these observations on the grounds that South African universities have "never managed to achieve anything like institutional autonomy, neither in principle nor in practice". Given that the 1997 legislation provided for cooperative governance of higher education institutions, du Toit $(2014$, p.3) holds that this foundational framework of the post-apartheid democratic governance "has explicitly ruled out institutional autonomy as a basic right, just as much as it abjured the state's prerogative for direct control of universities". Managerialism became triumphant in the governance of the South African University, especially with the 1996 neoliberal state and 2008 DoHET interventions.

\subsection{Triumphalism of Managerialism in Governance of the South African University}

Managerialism was exerted in earnest since at least 2008 through pronouncements of subject matter classifications and the national qualifications framework (DoHET, 2008a, 2008b). These pronouncements introduced a rigid funding model for the South African University, which invoked notions of notional learning hours, HEMIS credits, full-time equivalents (FTEs), senior lecturer equivalents (SLEs), Funding Grid Factor, market-linked National Qualifications Framework (NQF) as well as reincarnation of pass, graduation, retention, success and throughput rates as key performance areas. Once imposed, these requirements and measures affirmed triumphalism of managerialism over transformational leadership. On its part, the 2012 legislative revisionism was designed to extend state powers for intervention in the governance of the South African University.

HESA's observation, relating to the 2012 legislative amendment of laws, was that they posed "a threat to the institutional autonomy of universities in an attempt to bring them under the direct control of the Ministry" (cited in du Toit, 2014, p.2). Simultaneously, there was leadership instability, public contestations, paucity of academic leadership, neoliberal globalization, mushrooming of virtual, private and corporate universities as well as "growing corporatization, rampant managerialism and state control" of the higher education system, all of which colluded to render university leadership virtually non-transformational. Notwithstanding the $1996 \mathrm{NCHE}$ proposal of co-operative governance, the state has always modified practice in order to exercise greater control and to intensify marketization (Symes, 2005, p.25 cited in du Toit, 2014, p.4). Often, it is argued that the 1997 White Paper, the 1998 Higher Education Act, its subsequent legislative amendments, and the 2001 NPHE did not conform to co-operative governance (Jansen, 2003; du Toit, 2014). In 2002, the Task Team on Governance in Higher Education of the CHE cautioned that continued use of the notion of cooperative governance when it no longer applied could cause confusion and hinder policy development for good practice (Jansen, 2003; du Toit, 2014).

The CHE (2001) describes the plans for mergers and incorporations in the National Plan for Higher Education Policy with the provision that the new universities will require new visions, missions and cultures. Regarding governance 
of the merged universities, the $\mathrm{MoE}$ (2003) merely stipulates that it is important not to have leadership and management vacuum in the process of their execution. That is, the MoE's (2003) primary governance concern relating to mergers and incorporations was focused on managerial leadership. Rather than create advantage for the leadership of universities, shifting policy and legislative measures have instead compounded the dilemmas embedded with the prevalence of managerialism amidst the expectation for transformational leadership and creation of learning organizations. Furthermore, the shifts complicated the duties and roles of university leadership because restructuring of powers for managerialism had paradoxical discrepancies with the requirements for transformational characters such as taking control, being decisive, making judgments, using common sense, being effective and responsive, and recognizing the general picture whilst acting on specificities of circumstances. The DoHET's 2012 amendment of laws has inescapably altered the dynamics of university leadership, given the precarious relationships with state and society as well as the imperatives of balancing competing demands, interests and goals as well as the imperatives of globalization, internationalization and micro-geopolitics.

At the core of managerialism is the nuance requirement that universities be managed as business. But the applicability of managerial leadership to the South African University has always been questionable on the grounds that it involved a virtual transplant of principles of business environment into the public sector. Jansen et al. (2001, p.37) conclude that the "loss of institutional autonomy is real, given the regulatory framework" imposed by SAQA, the CHE and the DoHET. The imposition of corporate style management such as in the Executive Deans and School Directors, has meant that "the regulatory role of the state, the expanding role of markets and the influential role of international agencies" would become primate (Jansen et al., 2001, p.37). Conversely, university governance required "strong and visionary leadership" (Jansen, 2003; Fernandez, 2005; Louw \& Zuber-Skerritt, 2009; Chipunza \& Gwarinda, 2010). As elsewhere, governance of the South African University required "the human heart (which) is the heart of the matter of leadership development" (Zuber-Skerritt, 2007, p.1003). Indeed, governance of the South African University has to "integrate heart and head in a holistic way ... (and) combine soft and hard" management strategies in order for leaders to "serve as role models, mentors, coaches, co-learners, co-researchers and co-leaders" (Zuber-Skerritt, 2007, p.1003) rather than managerialism.

\subsection{Transformational Leadership Challenges for the South African University}

Universities are necessarily often controversial because they create space for critical public discourse; and, these institutions are sometimes brutally repressed and financially strangulated under authoritarianism (Jansen, 2003; Mkandawire, 2005, 2011). Similarly, authoritarianism and democratization create peculiar stressors for universities, which tend to be blamed on the conduct of these institutions themselves. As Mkandawire (2011, p.22) observes,

"The collapse of the educational system, the parlous state of Africa's publishing industry and the academic rituals and traditions of footnoting and citation, the self-inflicted misrepresentation by the many buffoons that somehow strutted and fretted on the centre stage of African politics ... the cumulative effect of all this was tantamount to self-erasure".

Under restructuring, governance of the South African University virtually emulated the nuance hybrid of stateowned enterprises. The MoE's (2003) requirement for good governance did not provide for attendant structures, processes and systems necessary for instilling transformational institutional leadership characterized by "charisma, inspiration, intellectual stimulation and individual consideration" (Chipunza \& Gwarinda, 2010, p.2). With state control and interference, amidst competition and decreased public funding, expectation of transformational leadership was unrealistic. However, the South African University consists of enduring colonial and apartheid legacies (Tilak, 2011), which render their democratic governance potentially paradoxical as decisions are unavoidably shaped by cultural, ideological, historical and geographical factors (Jansen, 2003; Jack, 2007). Under the testing and changeable relationships between university, the state and society governance of the South African University is, ironically, required to achieve a judicious mix of "intelligence and experience" as well as exceptional "ability to see (and foresee) diverse components" as business (Nolte, n.d.).

Pack leadership has been identified as a unique style for South Africa where it is necessary to almost always adopt a "mixture" of "benevolent dictatorship, cultivated autocracy" and "shuttle collaboration" wherein opposed viewpoints and public contestations make for nuance "perspectives, unusual, counter-trend ideas" rather than marginalization of weaker actors and tolerance of divisive conduct (Nolte, n.d., p.134). Prospects for survival of the South African University, under circumstances of turbulence, instability and uncertainty, have depended on transformational leadership, which has been in abundance, contrary to commonly held perceptions of its dearth (Jansen, 2003; Vinger \& Cilliers, 2006; Louw \& Zuber- 
Skerritt, 2009; Chipunza \& Gwarinda, 2010). Given the insistence on the application of democratic principles, transformational leadership of the South African University has faced serious governance dilemmas relating to how to create commonly shared distinct institutional culture and vision out of, sometimes, contradictory cultures, procedures, systems and policies held by faculty whose geopolitical self-imaginary remained largely frozen in the past. As Chipunza \& Gwarinda (2010, p.3) put it, a common cultural identity "develops on the basis of shared vision and mission, strategy, policies, systems and procedures", which have to a significant degree been contested and complicated by the intensity of managerialism, dearth of enabling policy and legislation as well as the increased threat of state interference in the governance of the South African University.

Simultaneously with the funder-state emphasis on managerialism, governance of the South African University was paradoxically expected to be constructive, effective, courageous, and bold, as well as to rely on self-believe, common sense, balanced judgment and to take control of the specific tasks at hand whilst remaining generalists (Nolte, n.d.; Louw \& Zuber-Skerritt, 2009; Chipunza \& Gwarinda, 2010). These paradoxical expectations meant that the South African University was expected to exercise transformational leadership within the environment of increasing overbureacratization and managerialism. For this reason, the South African University has been involved in "the creation and advancement of knowledge" whilst remaining a "generally poor" learning organization itself (Nolte, n.d., p.124). Jansen et al. (2001, p.32), drawing from Scott (1998), characterizes the South African University as "creator, interpreter and sufferer" of globalization imperatives. Given the specific national and international objectives set for universities, their governance has been required to create and recreate these institutions into learning organizations, increasingly placing leadership under complex challenges occasioned by their changing relationships with the state, societal and global actors (Nolte, n.d.; Jansen, 2003; Louw \& Zuber-Skerritt, 2009; Chipunza \& Gwarinda, 2010; Dominguez-Whitehead, 2011; du Toit, 2014).

Amidst these challenges, the South African University has to be governed and led in ways that ensure that it remained legible to various stakeholders and, simultaneously, "become responsive to a pervasive rhetoric of innovation and entrepreneurship" (Knievel \& Sheridan-Rabideau, 2009, p.36). Jansen's (2004, p.5 cited in du Toit, 2014, p.2) observation reveals a paradox of a "gradual but systematic erosion of historical standards of autonomy that were ingrained within the institutional fabric of universities, thus redefining conceptions of institutional autonomy as the state systematically acquires new forms of power over the universities through a series of policy and regulatory-based incursions". Within this same rigid governance environment, leadership of the South African University has been expected to take control, have self-believe, be decisive, effective and responsive, focus simultaneously on specifics and the general picture, make judgments, display common sense, demonstrate intelligence and experience, and "be all things to all" in the hope of creating learning organizations (Nolte, n.d.; Jansen, 2003; du Toit, 2014). Whereas notions of "pack" leadership have been commonly flouted for theoretical convenience, pragmatism dictates that leadership of the South African University has come down to individual responsibilities and qualities, largely subsumed to triumphal managerialism.

\section{State Funding Model for the South African University}

The South African University was confronted with challenges relating to student finances, race and gender bias, security, as well as internal and external geopolitics; and, its leadership was expected, sometimes unfairly, to open doors for a diverse body of students whilst having to obey dictates of managerialism, intake quotas, business ethos and limitations of both public funding and physical infrastructure provisions. Also, leadership was required to ensure that universities operate and compete both nationally and globally, notwithstanding the requirement for rigid over-bureaucratization and fixed managerialism. The major institutional management challenge has been, according to Nolte (n.d., p.135), finding "the niche that is most compatible with the institution's ... inherent strengths and the opportunities that exist in its environment". The restructuring burden was devolved to university leadership amidst paradoxes related to "co-operative governance", managerialism, "institutional autonomy" and extension of state control (Nolte, n.d.; du Toit, 2014). The extension of the powers of the Minister of the DoHET to intervene reached beyond universities that are unable to address their own management and governance affairs to encompass the rest of the higher education sector (du Toit, 2014). Simultaneously, university leadership has been required to play a critical role in the creation of learning organizations as well as the attendant institutional performance and/or under-performance amidst "conditions of turmoil, socio-economic instability and future uncertainty" (Nolte, n.d., p.134). To ensure itself of exacting control over the South African University, the state designed a funding formula that relies heavily on student enrolment simultaneously with prescribed intake quotas.

Reliance on full-time equivalents (FTEs) for funding was formally inaugurated through adoption of the 
Classification of Educational Subject Matter (CESM), which defines determined areas of specialization and major fields of study. Whereas the South African University is challenged to define its competitive niche in terms of the opportunities and advantages inherent to the environment, the CESM as defined by the DoHET (2008a) have imposed limitations because they are used to determine funding categories. Inevitably, those universities whose strengths are in humanities and social sciences receive reduced funding relative to natural sciences. The re-categorization of CESM groups from 22 to 20 between 2009 and 2010 (table 1) is the clearest demonstration of the precariousness of this state funding model. Funding of modules and qualifications on the bases of CESM categories, relied on "unduplicated headcount enrolments" where required in funding formula calculations (University of Limpopo, 2010, p.11).

Table 1: Re-categorization of CESM Funding Groups, 2009 and 2010

\begin{tabular}{|l|l|l|}
\hline $\mathbf{2 2}$ CESM Funding Groups, 2009 & $\mathbf{2 0}$ CESM Funding Groups, 2010 & $\begin{array}{l}\text { Funding Group } \\
\text { Weighting, 2009 \& 2010 }\end{array}$ \\
\hline $\begin{array}{l}\text { Education; Law; Librarianship; Psychology; } \\
\text { Social Services/Public Administration }\end{array}$ & Education; Law; Psychology; Public Management \& Services & 1.0 \\
\hline $\begin{array}{l}\text { Business/Commerce; Communication; } \\
\text { Computer Science; Languages; } \\
\text { Philosophy/Religion; Social Sciences }\end{array}$ & $\begin{array}{l}\text { Business, Economics \& Management Studies; Communication, } \\
\text { Journalism \& Related Studies; Computer \& Information } \\
\text { Sciences; Languages, Linguistics \& Literature; Philosophy, } \\
\text { Religion \& Theology; Social Sciences }\end{array}$ & 1.5 \\
\hline $\begin{array}{l}\text { Architecture/Planning; Engineering; Home } \\
\text { Economics; Industrial Arts; Mathematical } \\
\text { Sciences; Physical education }\end{array}$ & $\begin{array}{l}\text { Architecture \& the Built Environment; Engineering; Family } \\
\text { Ecology \& Consumer Sciences; Mathematics \& Statistics }\end{array}$ & 2.5 \\
\hline $\begin{array}{l}\text { Agriculture; Fine \& Performing Arts; Health } \\
\text { Sciences; Life \& Physical Sciences }\end{array}$ & $\begin{array}{l}\text { Agriculture; Agricultural Operations \& Related Sciences; Visual } \\
\text { \& Performing Arts; Health Professions \& Related Clinical } \\
\text { Sciences; Life Sciences; Physical Sciences }\end{array}$ & 3.5 \\
\hline
\end{tabular}

Source: DoHET, 2008a

Full-time equivalent (FTE) refers to student enrolment of a standard full-time curriculum for qualification. Related to the FTEs are the senior lecturer equivalents (SLEs), described as

"the total recurrent and non-recurrent costs for full-time and part-time academic staff members (including all tutors and demonstrators), divided by the rand equivalent of a senior lecturer cost unit for the year in question. This represents the average cost-of-employment of permanent academic staff members across a rank range from tutor to professor" (University of Limpopo, 2010, p.19).

SLEs, arranged in terms of specific ranks (table 2), are crucial for determining the staff capacity of academic units because they relate to the DoHET funding model for the South African University. FTEs are used to determine the official DoHET Funding Grid Factor, which classifies modules in terms of funding groups (see table 1) and course levels 00 to 09 (old) or 01 to 10 (new). The DoHET has always tacitly expected the South African University to operate at $70 \%$ of the SLEs in respect of staff capacity, in keeping with efficiencies and efficacies of market economics.

Table 2: DoHET Pre-determined Senior Lecturer Equivalents and Full-time Equivalents by Academic Rank

\begin{tabular}{|l|c|}
\hline Academic Rank & SLEs \\
\hline Tutor & 0.50 \\
\hline Lecturer & 0.75 \\
\hline Senior Lecturer & 1.00 \\
\hline Associate Professor & 1.25 \\
\hline Professor & 1.50 \\
\hline
\end{tabular}

Source: DoHET, 2008b

Modules and qualifications are awarded credits, which are conceived through notional hours and are supposedly indicative of "the volume of learning required for the completion of a module or qualification" (University of Limpopo, 2010, p.6). Whereas the Higher Education Management Information System (HEMIS) module credit refers to "the fraction of a 
full-time curriculum in a year of study of a specific ... qualification credit", the South African Qualifications Authority (SAQA) module credit is the numerical unit drawn from notional hours of learning "to communicate the academic weight of a module" wherein one credit is equivalent to 10 notional learning hours (University of Limpopo, 2010, pp.6, 7). One HEMIS credit is allocated per year level of learning, implying that a three year qualification consists of a total of three, whilst 120 SAQA credits are normally allocated per year, totalling an average of 360 for a three year qualification (DoHET, 2008b). HEMIS replaces the old terminology of the South African Post-Secondary Education (SAPSE).

Note has to be made that learning hours are determined in a technocratic sense wherein the time that an average learner would require to achieve the learning outcomes is calculated on the bases of combinations of hours spent for contact sessions, preparation, writing assessments, presentations, tutorials, practical work as well as formal, structured, experiential and independent learning. As already indicated, a so-called informed decision is made to estimate that one SAQA credit equals 10 notional hours (DoHET, 2008b). Ultimately, the National Qualification Framework (NQF) was imposed through market requirements as guideline of the boundaries for standardization and accreditation of qualifications according to skills and knowledge mastered. Manifestations of managerialism are evident in the adoption of pass, graduation, retention, success and throughput rates as performance indicators. The DoHET (2008b) has predetermined graduation rates as manual benchmarks for the South African University (table 3). It uses these benchmarks to compute FTE enrolments per qualification using a series of cumbersome formulae.

Table 3: DoHET Benchmark Graduation Rates (\%)

\begin{tabular}{|l|c|c|}
\hline Qualification & Benchmark Graduation Rate & Reduced Rate \\
\hline General Academic First Bachelors' Degrees & 25 & 22.5 \\
\hline Professional First Bachelors' Degrees & 20 & 18 \\
\hline Postgraduate Diplomas & 60 & 54 \\
\hline Honours Degrees & 60 & 54 \\
\hline Masters Degrees & 33 & 30 \\
\hline Doctoral Degrees & 20 & - \\
\hline
\end{tabular}

Source: DoHET, 2008b

These expectations have emphasized managerialism rather than transformation; and, the South African University has been at pains delivering according to these quantitative norms. Whereas policy shifts have always had an appearance of transformational promise, restructuring of universities has been bedevilled by experiences of disempowerment (Oxlund, 2010; Dominguez-Whitehead, 2011), which tacitly precluded the exercise of transformational leadership. Tilak (2011, p.29) notes that "public financing of higher education is still the best and most prevalent method of developing strong and vibrant higher education systems"; and, du Toit $(2014$, p.1) observes that the twenty years of concerted comprehensive restructuring of higher education in South Africa have seen the DoHET interventions meet with fierce responses and rejectionism from stakeholders such as HESA, revealing that this country has "reached a critical juncture in the governance of higher education, a belated moment of truth - even if its precise nature remains to be clarified". But state funding of the South African University on the bases of full-time equivalent (FTE) units that are inextricably linked to enrolments, modules passed and overall throughput rate of qualifications, amidst imposition of intake quotas, is pure emphasis on managerialism above transformational leadership. Further, the organizational, administrative and academic unit of the South African University consists of faculty, school and department, some of which contain evidently disparate disciplines, teaching and research niches. The South African University is required to be mechanically managerial in its operations, placing qualitative transformation in the backseat.

\section{Conclusion}

This article argued that the DoHET's 2008 interventions have affirmed the triumph of managerialism over transformational leadership in the governance of the South African University. Reverence for managerialism and over-bureaucratization eroded the necessary public space for innovativeness, imaginativeness, risk-taking, application of common sense and experimentation required for the transformation of the South African University. The most vivid manifestation of the triumph of managerialism is in the DoHET's mechanically technocratic funding model for the South African University. The article supports the notion that restructuring of the South African University could in the final analysis "signal a decisive triumph of the neoliberal state where the logic of markets ... and state interventionism ... might, simply and 
effectively, resolve the fate of weak universities" (Jansen et al., 2001, p.37). The article concludes that the potential for transformational leadership has faced intractable governance dilemmas of a disabling environment that is diametrically opposed to qualities of charisma, inspiration, intellectual stimulation and individual consideration. It suggests that the present South African University yawns for re-humanize, democratization and collaborative strategies which, in ZuberSkerritt's (2007, p.1003) phraseology, place emphasis on personal relationships, cross-cultural communications, integration of heart and head, judicious mix of soft and hard tactics as well as process and knowledge management, wherein leaders serve simultaneously as "role models, mentors, coaches, co-learners, co-researchers and co-leaders", given historical legacies of apartheid and racial discrimination.

\section{References}

Barnes, T. 2006. Changing discourses and meanings of redress in South African higher education, 1994-2001. Journal of Asian and African Studies, 41(1/2), 149-170.

Beckman, B. \& Adeoti, G. 2006. Intellectuals and African Development: Pretension and Resistance in African Politics. Zed Books, London.

Cassim, S. 2005. Reflections on equity and diversity at higher education institutions in South Africa. South African Journal of Higher Education, 19(4), 653-665.

Chipunza, C. \& Gwarinda, S.A. 2010. Transformational leadership in merging higher education institutions: A case study. South African Journal of Human Resource Management, 8(1), 1-10.

Council on Higher Education (CHE), 2001. Promoting Good Governance in South African Higher Education. CHE, Pretoria.

Czerniewicz, L. \& Brown, C. 2009. A study of the relationship between institutional policy, organisational culture and e-learning use in four South African universities. Computers \& Education, 53, 121-131.

Department of Education (DoE), 1997. White Paper 3: A Programme for the Transformation of Higher Education. DoE, Pretoria.

Department of Education (DoE), 2001. National Plan for Higher Education. DoE, Pretoria.

Department of Higher Education and Training (DoHET), 2008a. Classification of Educational Subject Matter (CESM). DoHET, Pretoria.

Department of Higher Education and Training (DoHET), 2008b. The Higher Education Qualifications Framework. DoHET, Pretoria.

Department of Higher Education and Training (DoHET), 2012. Higher Education and Training Laws Amendment Act 23 of 2012. DoHET, Pretoria.

Dominguez-Whitehead, Y. 2011. Executive university managers' experiences of strike and protest activity: A qualitative case study of a South African university. South African Journal of Higher Education, 25(7), 1310-1228.

Du Toit, A. 2014. Revisiting "Co-operative Governance" in Higher Education: A Discussion Document. HESA, Pretoria.

Fernandez, S. 2005. Developing and testing an integrative framework of Public sector leadership: Evidence from the public education arena. Journal of Public Administration, 15(2), 197-208.

Jack, L. 2007. Reflections on the merger experience of Walter Sisulu University. Discourse, 35(1), n.p.

Jansen, J. 2003. Mergers in South African higher education: Theorizing change in transitional contexts. Politikon, 30(1), 27-35.

Jansen, J.D., Habib, A., Gibbon, P. \& Parekh, A. 2001. Accounting for change: the micropolitics of university restructuring - Part three: global pressures, local responses. South African Journal of Higher Education, 15(3), 32-38.

Knievel, M. \& Sheridan-Rabideau, M.P. 2009. Articulating "responsivity" in context: re-marking the M.A. in composition and rhetoric for the electronic age. Computers and Composition, 26, 24-37.

Louw, I. \& Zuber-Skerritt, O. 2009. Reflecting on a leadership development programme: A case study in South African higher education. Perspectives in Education, 27(3), 237-246.

Maistry, S.M. \& Ramdhani, J. 2010. Managing tensions in a service-learning programme: Some reflections. South African Journal of Higher Education, 24(4), 555-567.

Marginson, S. 2010. Higher education in the global knowledge economy. Procedia Social \& Behavioral Sciences, 2, 6962-6980.

Ministry of Education (MoE), 2003. Higher Education Restructuring and Transformation: Guidelines for Mergers and Incorporations. MoE, Pretoria.

Mkandawire, T. (ed.), 2005. African Intellectuals: Rethinking Politics, Language, Gender and Development. Zed Books, London.

Mkandawire, T. 2011. Running while others walk: Knowledge and the challenge of Africa's development. Africa Development, XXXVI(2), $1-36$.

National Commission on Higher Education (NCHE), 1996. A Framework for Transformation (NCHE Final Report). NCHE, Pretoria.

Nolte, D.A. n.d. Higher education system and institutional management trends and challenges. Technickon Witwatersrand, Johannesburg.

Northouse, P.G. 2001. Leadership: Theory and Practice. SAGE, Thousand Oaks, CA.

Oxlund, B. 2010. Responding to university reform in South Africa: Student activism at the University of Limpopo. Social Anthropology, 18(1), 30-42.

Tilak, J.B.G. 2011. Financing higher education in Sub-Saharan Africa. Africanus, 41(2), 4-31.

Toni, N. 2011. Dismantling racial and hegemonic boundaries for an inclusive higher education. Africa Insight, 40(4), 187-197.

Van der Westhuizen, C.N. 2004. The games institutions play or the impact of university incorporation on the attitudes, beliefs and perceptions of college lecturers. South African Journal of Higher Education, 18(1), 153-164. 
University of Limpopo, 2010. Institutional Planning Definitions and Codes. Sovenga, Institutional Research and Planning.

Vinger, G. \& Cilliers, F. 2006. Effective transformational leadership behaviours for managing change. South African Journal of Human Resource Management, 4(2), 1-9

White, K. Carvalho, T. \& Riordan, S. 2011. Gender, power and managerialism in universities. Journal of Higher Education Policy and Management, 33(2), 179-188.

White, K., Riordan, S., Ozkanli, O. \& Neale, J. 2010. Cross cultural perspectives of gender and management in universities. South African Journal of Higher Education, 24(4), 646-660.

Zuber-Skerritt, O. 2007. Leadership development in South African higher education: The heart of the matter. South African Journal of Higher Education, 21(7), 984-1005. 